\title{
Manley and Bishop: The Tragedy of Leftist Reformism in the Caribbean
}

\author{
Tristan Scott 2T1 \\ University of Toronto \\ FAS Human Geography, Geographic Information Systems, Environmental Studies
}

\section{A B S T R A C T}

The Caribbean and Latin America has been home to numerous leftist and populist political experiments during the 20th century, most of which have in turn experienced some level of retaliation from the capitalist Global North. Jamaica under Michael Manley and Grenada under Maurice Bishop are two such examples, and both can be evaluated for their choice in pursuing relatively moderate, reformist left-wing policies - neither of which permanently dismantled capitalist institutions in their respective states. Yet, both countries were ultimately subject to destabilization efforts from the capitalistic Global North, which sought to maintain its political and economic hold over the region. This paper examines leftist reformist policies (as opposed to revolutionary policies) in Jamaica, and Grenada, and observes how even the most moderate econom-

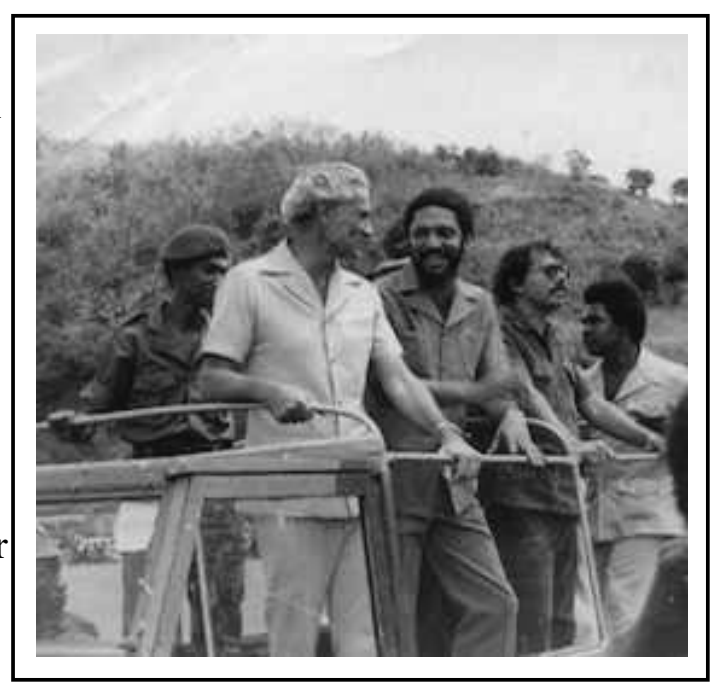

Keywords: Michael Manley, Maurice Bishop, Caribbean Socialism, Reform vs Revolution, Capitalism, Colonialism ic policies looking to curb capitalism's most harmful negative externalities are still viewed as a near-existential threat by institutions in the Global North.

\section{B I O}

Tristan Scott is a recent graduate from the University of Toronto, majoring in Human Geography, Geographic Information Systems, and Environmental Studies. Tristan's academic interests include urban planning, data analytics, history, and political science, particularly as it concerns the intricacies of left-wing politics and neoliberalism. 


\section{Introduction}

As a historically colonized and racialized region of the world, the Caribbean has been subject to the influence of foreign actors, particularly those residing in the Global North. As the concepts of empire and colonial rule became untenable in the post-Second World War era, capitalism as a means maintaining wealth accumulation in the periphery rose to the forefront. ${ }^{1}$ Through management infrastructures such as the U.S-built and Global North-supported Bretton Woods institutions, former colonies such as those in the Caribbean would have to take on liberal economic policies such as structural adjustment programmes, privatization, and initiate a reduction of market regulations. If a newly independent Caribbean state had any hope of developing while also maintaining cordial relations with the wealthy Global North, they would have to sacrifice any ideas of formulating alternative, nation-specific forms of governance.

In addition, with the United States emerging as the hegemonic power of the West after the Second World War, it was given relatively free reign to impose its own economic ideals over much of the Global South. ${ }^{3}$ By extending the influence of American monopolies, controlling supply chains, wielding its advanced and mobile army, and flooding the region with American products, the United States turned the Caribbean and Latin America into its own personal "backyard" - a region firmly in its sphere of influence. With capital flows replacing the territorial boundaries associ ated with the empires of the past, the United States successfully recreated a form of economic imperialism in the present.

Although world history is marked by numerous violent and revolutionary attempts at breaking the bonds presented by political and economic colonialism, the Caribbean has been noted for attempting change via moderate reformist methods. This paper will examine Jamaica under the Michael Manley government and Grenada under Maurice Bishop and the New Jewel Movement, arguing that reformist methods in the Global South, despite their tendencies toward upholding capitalistic institutions, are seen as being just as threatening as their revolutionary counterparts in the minds of Global North actors.

\section{Jamaica Before and After Indepen- dence: Alexander Bustamante and the State}

Jamaica prior to independence was grappling with the final vestiges of overt colonialism and was largely subject to the influence on Alexander Bustamante. According to Ambursley, the Bustamante Industrial Trade Union (BITU), which held control over much of Jamaican industry after the Second World War, was routed to defend the interests of both British and American capitalists. ${ }^{5}$ Indeed, it was under the management of Bustamante himself that the BITU threatened a worker strike against Clement Atlee, then Prime Minister of the United Kingdom, who proposed nationalizing two of the

${ }^{1}$ C. B. Davies \& M. Jardine, "Imperial Geographies and Caribbean Nationalism: At the border between "A Dying Colonialism' and U.S. Hegemony” (2003).

2 Ibid.

3 Ibid.

4 Ibid.

5 F. Ambursley, “Jamaica: The Demise of 'Democratic Socialism””. New Left Review, 128 (1981), 76. 
island's sugar monopolies. ${ }^{6}$ Paired with the influence of Bustamante, Jamaica's path to industrialization would be based upon the policy of "industrialization by invitation" (IDI), devised by St. Lucian economist W. Arthur Lewis. Wanting to shift the Caribbean away from its primary export of agriculture, Lewis called for creating an economic atmosphere that was attractive to foreign investment, therefore kickstarting industrialization? Caribbean leaders would be required to keep wages low to entice existing companies. ${ }^{8}$ Lewis also recommended the creation of a Caribbean-wide Industrial Development Corporation and an Industrial Development Bank, with the former providing investment to the region while the latter offered loans to companies.9. Lewis appeared to envision a firmly capitalistic economic order for the region, where industry and wealth provided by Europe and North America would "trickle down" to locals.

With Caribbean governments tagging on their own tax incentives for prospective businesses, the region adopted IDI policies across the $1950 \mathrm{~s}^{10} .^{0}$ The process of industrialization was therefore attached to the movements of foreign capitalists, who had the space to operate across the Caribbean virtually free of charge. It must be mentioned that the welfare of Caribbean labourers goes unaddressed in Lewis' policy. Attempts at improving the material well-being of workers would therefore be a secondary or nonexistent goal in the eyes

${ }^{6}$ Ibid

7 J.R. Mandle, Patterns of Caribbean Development: An Interpretive Essay on Economic Change (Routledge, 1982).

${ }^{8}$ Ibid.

${ }^{9}$ Ibid

10 Ibid.

${ }^{11}$ F. Ambursley, “Jamaica: The Demise of 'Democratic Socialism'”. New Left Review, 128 (1981): 76.

12 Ibid.

13 Ibid.

14 "Jamaica vs. the Transnationals: Battle Over Bauxite," NACLA Report on the Americas, 12:3, (1978): 17-25,

${ }^{15}$ Ibid of capitalists such as Lewis and Bustamante.

\section{Michael Manley and the Liberation} of Jamaica via Reformist Means

With financial downturns and widening wealth inequalities occurring throughout the 1960s, Jamaica's People's National Party under Michael Manley won the 1972 election. Manley adopted the phrases of "Betta Mus Come" and "Power to the People", signalling that his party would be adopting a populist edge in their management of Jamaica. ${ }^{11}$ Initial social and economic reforms included universal secondary education, lifting bans on Black Liberation and Marxist literature, and the initiation of nationalization programmes! ${ }^{2}$ Manley also announced his intentions to renegotiate bauxite and alumina royalty agreements with Canadian and American corporations. ${ }^{13}$ In addition, a levy upon bauxite was applied country-wide, raising tax rates by $480 \%$ by 1975 , amounting to a total increase from $\$ 2.50$ to $\$ 14.51$ per tonne. ${ }^{14}$ International goals included the formation of the International Bauxite Association, which would bring together numerous Global South countries. Finally, Manley voiced his support for Black Liberation movements across the African continent. ${ }^{5}$ 
Topping off his shift away from the capitalistic norms established by British colonists and Bustamante, the PNP published its "Thirteen Principles of Democratic Socialism”. Manley particularly noted that his democratic socialist ideal for Jamaica "... was the philosophy that best gives expression to the Christian ideal of equality of all God's children". ${ }^{16}$

As evidenced by the ambitious reforms of the early 1970s, the Manley government had the aim of redistributing wealth and supporting liberation movements worldwide, all of which fall in line with the leftist goals advocated by the PNP's version of democratic socialism. However, a question yet remains: did the goals of Manley and the PNP truly fall within the bounds of democratic socialism, and perhaps most importantly, were they conducive to eventually dismantling capitalism in Jamaica?

\section{Democratic Socialism and Social Democracy}

The Democratic Socialists of America define democratic socialism as a system in which "...the economy and society should be run democratically - to meet public needs, not to make profits for the few". ${ }^{17}$ Similarly, Bolton states that democratic socialism looks to dismantle the concept of private property while ensuring that production is run democratically by workers in an alliance with the state. ${ }^{8} \mathrm{As}$ such, the needs of workers and of society at large, rather than those of a capitalist or a group of shareholders, are to be emphasized and supported. As a form of socialism which depends upon democratic consensus, democratic socialism is opposed to state-based, centrally planned forms of socialism, commonly found in Marxist-Leninist communist states such as the Soviet Union and Cuba during the 20th and 21 st centuries. ${ }^{19}$

In detailing the erosion of democratic socialism in Jamaica, Graham states that Michael Manley's reforms were firmly moderate and non-revolutionary, with no calls for seizing control over Jamaican capital. ${ }^{20}$ Capitalism under the PNP would instead seek to "domesticate" capitalism through nationalization, the establishment of welfare infrastructure, and the creation of rural cooperatives. ${ }^{21}$ Manley looked to forge a "third path" for Jamaica, one which differed from both traditional neocolonial models of capitalism and the state-based Marxist-Leninist form of communism. ${ }^{22}$ As such, it could be argued that the form of democratic socialism implemented by the Manley government was instead a form of social democracy, which calls for wealth redistribution, social safety nets, and government economic intervention as a means of countering the often-harmful

16 C. Edie, "Domestic politics and external relations in Jamaica under Michael Manley, 1972-1980," Studies in Comparative International Development, 21(1), (2007): 1-94. https://doi.org/10.1007/BF02717364

17 Democratic Socialists of America. (n.d.). What is Democratic Socialism? https://www.dsausa.org/about-us/what-isdemocratic-socialism/

18 M. Bolton, “'Democratic Socialism' and the Concept of (Post)Capitalism,” . The Political Quarterly, 91(2), (2020): 334-342. https://doi.org/10.1111/1467-923X.12830

${ }^{19}$ Democratic Socialists of America. (n.d.). What is Democratic Socialism? https://www.dsausa.org/about-us/what-isdemocratic-socialism/

20 G. Graham, Democratic Political Tragedy in the Postcolony: The Tragedy of Postcoloniality in Michael Manley's Jamaica and Nelson Mandela's South Africa. (Routledge, 2018). https://doi.org/10.4324/9781315444529

${ }^{21}$ Ibid.

22 Ibid. 
consequences of capitalism and markets ${ }^{23}$ Capitalism as an economic system would therefore not be overthrown, but instead retooled to serve the needs of working-class Jamaicans. Therefore, there is no indication that Manley's form of "democratic socialism" would have ever brought about the true diminishment of capitalism and the onset of socialized control for working class Jamaicans. Manley's methods were not truly "revolutionary" in any meaning of the term - there would be no violent overthrowing of Jamaica's economic order nor an ousting of American and Global North influence from the island.

Additionally, citing the austerity measures taken by France, Britain, Sweden, and Germany, Lavelle states that social democratic governments ultimately capitulate to capitalistic pressures, either from within the government apparatus itself or from capitalist influence elsewhere ${ }^{24}$ Citing Callinicos, Lavelle argues that social democratic reforms are prone to significant reactions from big business, including capital flight, which can destabilize a government ${ }^{25}$ Such a point can be observed in the eventual demise of the Manley government and the reactionary responses seen towards their bauxite levy, which resulted in domestic business circles moving their wealth abroad. As a result, capital inflow as a measure of the island's GDP shrank from $9.7 \%$ to $0.9 \%$ as countries looked elsewhere for profit maximi- zation. ${ }^{26}$ Additionally, the US moved to support the political ambitions of the liberal capitalist Jamaica Labour Party, while American media initiated a smear campaign against the Jamaican tourism industry. ${ }^{27}$ By undercutting two of Jamaica's largest industries, tourism and mining, the nation was left economically devastated.

Such an economic situation rendered Manley's reformist goals impossible to meaningfully achieve. Lavelle notes that within a functioning social democracy, constant economic growth for financing its robust social programs is an absolute necessity. ${ }^{28}$ Therefore, social democrats and reformist socialists such as Manley often fall into a "catch-22", where they attempt to declaw capitalist institutions while simultaneously attempting to maximize the funds that can be siphoned from them.

Countries such as the European nations analyzed by Lavelle or Jamaica under future liberal capitalist politicians often eventually end up sidelining social democratic reforms and choosing the opposing path of neoliberalism: the promotion of a strong free market via tax breaks, privatization, and deregulation. ${ }^{29}$ The post-Manley period, which saw the opposing Jamaica Labour Party ascend to rule under Edward Seaga, turn to the free market and the Global North for fixing Jamaica's financial woes. Agreements were struck with the International Monetary Fund,

23 A. Lavelle, The Death of Social Democracy: Political Consequences in the 21 st Century. (Routledge, 2008)

24 Ibid.

25 Ibid.

26 F. Ambursley, "Jamaica: The Demise of 'Democratic Socialism'”. New Left Review, 128 (1981): 76.

27 Ibid.

28 A. Lavelle, The Death of Social Democracy: Political Consequences in the 21st Century. (Routledge, 2008)

29 Ibid.

30 C. Edie, "Domestic politics and external relations in Jamaica under Michael Manley, 1972-1980," Studies in Comparative International Development, 21(1), (2007): 1-94. https://doi.org/10.1007/BF02717364.

31 A. Lavelle, The Death of Social Democracy: Political Consequences in the 21st Century. (Routledge, 2008), 13. 
regulations on companies were diminished, and austerity measures were introduced, resulting in sizeable cuts to Jamaican social programs ${ }_{30}$ Seaga's neoliberal goals aimed to create a "good business climate" in Jamaica by any means necessary, even if the result was a decline in social well-being. 31

It can therefore be determined that Jamaican social democracy, or "democratic socialism" as termed by Manley himself, may have been doomed from the start, and would not have eroded Jamaican capitalism. The structural problems inherent in Jamaican social democracy were further compounded by its position as an industrializing, majority-black, and formerly colonized state in the Global South. Unlike the industrialized and often formerly imperialist nations of Europe and North America, Jamaica lacked the international prestige and leverage required to go against British and American interests that were intent on exploiting the country's resources and claiming most of its wealth.

By observing the problems associated with social democracy, we see that the reformist policies of the PNP may have ironically moved Jamaica towards neoliberalism, which would have ultimately served the needs capitalists, given time. However, sensing danger, domestic and foreign actors quickly looked to dismantle Manley's relatively docile policies regardless. It becomes clear that even a measured, reform-based attempt at curbing the negative externalities associated with capitalism politics will result in significant backlash from Global North actors.

\section{Grenada's New Jewel Movement: Revolution via Reform}

Manley's attempt at achieving democratic socialism via reformist means can be contrasted with the New Jewel Movement (NJM), a Marxist-Leninist organization which overthrew the previous regime via revolutionary means while maintaining elements of capitalism during their rule.$^{32}$

Before the revolution, Eric Gairy served as Prime Minister of Grenada. His reign was noted as being rife with corruption, electoral fraud, and the usage of a paramilitary force which terrorized political threats and the island's citizens. ${ }^{33}$ It must be mentioned that the NJM, led by Maurice Bishop, initially attempted to bring about a leftist government via democratic means, wishing to uphold the electoral institutions that were, at least in theory, baked into the fabric of the relatively new country. ${ }^{34}$ It was only after multiple failed attempts at unseating the incumbent Gairy that the NJM turned towards vanguardism: where a political party serves as a community's sole centralized backbone for driving class struggle and a future revolution. ${ }^{35}$ Such parties are tightly centralized, with members required to strictly follow the party resolutions ${ }^{36}$ It was through such an organizational model that the NJM under Bishop was able to remain unified against the increasingly brutal and erratic actions taken by the Gairy government. ${ }^{37}$

\footnotetext{
32 D., Austin, "Vanguards and Masses: Global Lessons from the Grenada Revolution," Learning From the Ground Up: Global Perspectives on Social Movements and Knowledge Production. (2010): 175-191.

33 Ibid.

34 Ibid.

35 G.M. Telleria, "Vanguardism and the Vanguardist Organization: A Study of the Sandinista National Liberation Front and its Rise to Power," Latin American Policy, 8, (2017): 27-40. https://doi.org/10.1111/lamp.12115 36 Ibid.

37 Ibid
} 
In addition, the NJM also focused their efforts on uplifting the material and political conditions affecting women through the Progressive Women's Association (PWA). Although not initially viewing their fight through a socialist lens, the PWA advocated for employment opportunities, improved working conditions, and wages for women. ${ }^{38}$ Rather than purely attaining change along economic lines, Bishop acknowledged the identity-based wants of the PWA and incorporated them into the revolution. Looking to keep the party strong, the PRG did not tolerate the existence of multiple women's liberation groups, stating that a plurality could allow for CIA and other negative infiltration that could undermine the revolution. ${ }^{39}$

The adoption of vanguardism in the Grenadian contrast gave the NJM, and eventually the People's Revolutionary Government (PRG), a thoroughly revolutionary edge, which would eventually allow for a liberated Grenada to be fully unshackled from the racial and economic bounds provided by capitalism and allow for a transition to communism. It must be noted that although the NJM considered itself a Marxist and leftist political party, it pursued a mixed economy, recognizing that Grenada did not yet have the economic development required to fully bring about communism ${ }^{40}$. It can therefore be argued that although the Gairy government was overthrown through revolutionary means, the transition to communism would be done via reformist methods. As such, Bishop's government bears some level of resemblance to Manley's attempt at implementing social democracy in Jamaica. Although both countries in their experimentations with leftist politics ultimately kept their capitalist institutions intact, the NJM did so within the context of a centralized revolutionary government. The Marxist-Leninist idea of "Stagism" would evidently rule, where Grenada goes through a capitalist-tolerant phase until the economy was adequately developed and a significant proportion of the population was educated. ${ }^{41}$ Only then would full worker control over the means of production be viable without undermining the well-being of the state.

In terms of agricultural developments, Bishop's goals appeared tied to improving the material well-being of Grenadians at the most basic level. Goals included implementing price freezes upon staples and increasing the consumption of locally-grown products. ${ }^{42}$ According to Brierley, economic policy was seen in the creation of a "tri-sectoral" strategy, where Grenada's public, private, and cooperative sectors would work together towards common goals. ${ }^{43}$ Although the PRG was indeed left-wing, such an economic choice resulted in private corporations remaining firmly in place. To the astonishment of observers, the PRG saw an unemployment decrease from $49 \%$ before the revolution to $14 \%$ by 1983 . Furthermore, in contrast

38 N., Phillip, “Women in the Grenada Revolution, 1979-1983," Small Axe, 11(1), (2007): 39-66.

39 D., Austin, "Vanguards and Masses: Global Lessons from the Grenada Revolution," Learning From the Ground Up: Global Perspectives on Social Movements and Knowledge Production. (2010): 175-191.

40 R. Burtenshaw, Grenada's Revolution at 40. Jacobin, February 9 2019).

https://www.jacobinmag.com/2019/09/grenada-revolution-maurice-bishop-reagan

41 Marxists Internet Archive. (2018). "Stagism". Encyclopedia of Marxism, 2019.

42 J. Brierley, "A Review of Development Strategies and Programmes of the People's Revolutionary Government in Grenada, 1979-83". The Geographical Journal, 151(1), (1985): 40-52. doi:10.2307/633276

43 Ibid.

44 Ibid.

45 Ibid. 
to other nations in the Western Hemisphere that saw declines during and after the 1970 s recession, the island saw levels of sustained economic growth between the years of between 1979 to $1983 .^{45}$ However, despite Grenada's relatively capitalist-friendly approach, the United States and surrounding Caribbean nations still observed Bishop's government as a threat to neoliberal hegemony in the region, resulting in an American-led invasion in 1983 and the toppling of the PRG.

\section{Conclusion}

In observing the similarities and differences between Jamaica under Michael Manley and Grenada under Maurice Bishop, we recognize that political developments in the Caribbean are largely tied to the wants and whims of the Global North, largely due to the region being part of "America's Backyard". Although both countries have attempted to implement reformist methods that either would have resulted in the maintaining of capitalism or a gentle movement away from it, both saw significant backlashes from Global North actors. The US-led invasion of Grenada and the economic troubles experienced by the Jamaican PNP both acted as warnings to Global South and Caribbean countries during the late 20th century. Leftist policies that erode the neoliberal capitalistic hegemony will not be tolerated under any circumstances. As of 2021, both Jamaica and Grenada are managed by conservative, centre-right governments that adhere to the capitalistic policies which their predecessors sought to dismantle. For now, it appears as if the economic preferences of the Global North reign supreme across much of the Caribbean. It remains to be seen if leftist political forces can regain the level of prominence they once held in decades past and once again challenge the Global North for regional sovereignty. 


\section{Works Cited}

"Jamaica vs. the Transnationals: Battle Over Bauxite," NACLA Report on the Americas, 12:3, (1978): 17-25.

Ambursley, F. "Jamaica: The Demise of 'Democratic Socialism”". New Left Review, 128 (1981): 76.

Austin, D. "Vanguards and Masses: Global Lessons from the Grenada Revolution," Learning From the Ground Up: Global Perspectives on Social Movements and Knowledge Production. (2010): 175-191.

Bolton, M. “'Democratic Socialism' and the Concept of (Post)Capitalism," . The Political Quarterly, 91(2), (2020): 334-342. https://doi.org/10.1111/1467-923X.12830

Brierley, J. "A Review of Development Strategies and Programmes of the People's Revolutionary Government in Grenada, 1979-83". The Geographical Journal, 151 (1), (1985): 40-52. doi:10.2307/633276

Burtenshaw, R. Grenada's Revolution at 40. Jacobin, February 9 2019). https://www.jacobinmag.com/2019/09/grenada-revolution-maurice-bishop-reagan

Davies, C.B. \& Jardine, M. Imperial Geographies and Caribbean Nationalism: At the border between "A Dying Colonialism" and U.S. Hegemony (2003).

Democratic Socialists of America. (n.d.). What is Democratic Socialism? https:/www.dsausa.org/about-us/what-is-democratic-socialism/

Edie, C. "Domestic politics and external relations in Jamaica under Michael Manley, 1972-1980," Studies in Comparative International Development, 21(1), (2007): 1-94. https://doi.org/10.1007/BF02717364.

Graham, G. Democratic Political Tragedy in the Postcolony: The Tragedy of Postcoloniality in Michael Manley's Jamaica and Nelson Mandela's South Africa. (Routledge, 2018). https://doi.org/10.4324/9781315444529

Lavelle, A. The Death of Social Democracy: Political Consequences in the 21st Century. (Routledge, 2008), 13.

Mandle, J.R. Patterns of Caribbean Development: An Interpretive Essay on Economic Change (Routledge, 1982).

Marxists Internet Archive. (2018). "Stagism”. Encyclopedia of Marxism, 2019.

Phillip, N. (2007). "Women in the Grenada Revolution, 1979-1983," Small Axe, 11(1), (2007): 39-66.

Telleria, G.M. "Vanguardism and the Vanguardist Organization: A Study of the Sandinista National Liberation Front and its Rise to Power," Latin American Policy, 8, (2017): 27-40. https://doi.org/10.1111/lamp.12115 